\title{
Effect of weed control methods on growth of five temperate agroforestry tree species in Saskatchewan
}

\author{
by W.R. Schroeder ${ }^{1 *}$ and H. Naeem ${ }^{1}$
}

\begin{abstract}
Most tree species in agroforestry plantings are intolerant to vegetative competition and sites must be intensively cultivated to eliminate weeds. Many studies have been conducted to investigate what factors limit seedling growth because of the presence of vegetative competition in forest environments; however on agricultural sites there are few studies on weed management options for tree planting. This research quantified and compared growth of Manitoba maple (Acer negundo), green ash (Fraxinus pennsylvanica), Colorado spruce (Picea pungens), Scots pine (Pinus sylvestris) and Walker poplar (Populus $x$ Walker) in response to combinations of in-row and between-row weed control methods. The study was established on an agroforestry planting on agricultural soils in Saskatchewan. Treatments included in-row weed control using herbicides or plastic mulch and between-row weed control using tillage compared with a non-weeded control. Weed control positively affected annual height increment, basal diameter and height of the agroforestry species. The impacts of weed control versus no weed control were significant in almost all instances. However, tree species responded differently to the method of weed control. Weed control by herbicide and plastic mulch were not significantly different for four of the five species under investigation. This research will help with prescribing weed control methods for agroforestry and afforestation plantings on agricultural soils.
\end{abstract}

Key words: weed control, agroforestry, tree growth, plastic mulch, tillage, herbicide

\section{RÉSUMÉ}

La plupart des essences plantées en agroforesterie tolèrent mal la végétation compétitive et il faut donc effectuer un travail intensif du sol sur ces sites pour en éliminer les mauvaises herbes. Pour le milieu forestier on dénombre plusieurs études sur les facteurs qui affectent la croissance des semis lorsqu'ils sont soumis à une compétition végétale; en milieu agricole, les études se font toutefois plus rares sur les moyens pour contrôler les mauvaises herbes en plantation. Ce projet aura permis de quantifier et de comparer la croissance de lérable négondo (Acer negundo), du frêne vert (Fraxinus pennsylvanica), de lépinette du Colorado (Picea pungens), du pin d'Écosse (Pinus sylvestris) et du peuplier hybride Walker (Populus $x$ Walker) en réponse à diverses combinaisons de méthodes de désherbage dans les rangées de plants et entre celles-ci. Le dispositif détude a été établi dans une plantation agroforestière sur des terres agricoles de la Saskatchewan. Les traitements comprenaient un désherbage dans les rangées à l'aide d'herbicides ou de paillis de plastique, un travail du sol entre les rangées et enfin un témoin sans désherbage. Le désherbage a eu un effet positif sur la croissance annuelle en hauteur, la surface terrière et la hauteur des espèces agroforestières. Le désherbage a eu un impact significatif dans presque tous les cas en comparaison avec la situation sans traitement. Toutefois, les essences forestières nont eu les mêmes réactions aux divers traitements de désherbage. Le contrôle de la végétation au moyen d'herbicides et de paillis de plastique n’a pas montré de différence significative chez quatre des cinq essences à létude. Ce projet contribuera à prescrire des méthodes de désherbage pour les plantations agroforestières et de reboisement sur les terres agricoles.

Mots-clés: désherbage, agroforesterie, croissance des arbres, paillis de plastique, labour, herbicide

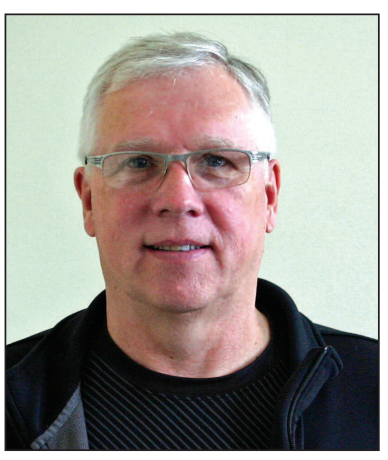

W.R. Schroeder

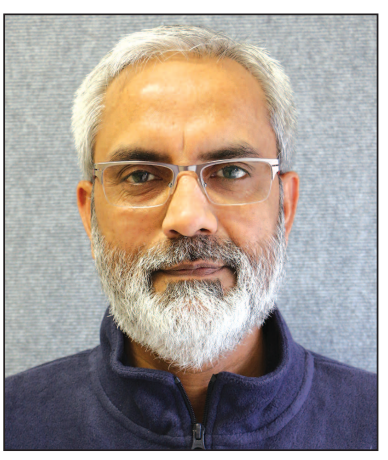

H. Naeem

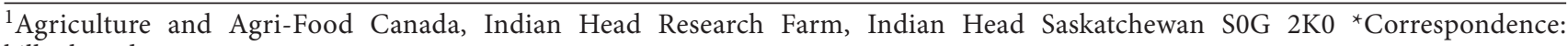
bill.schroeder@agr.gc.ca 


\section{Introduction}

In temperate regions, planted agroforestry systems, particularly windbreaks, are an important component of agroecosystems. Windbreaks contribute to producer productivity and environmental quality by increasing crop production while simultaneously reducing the level of off-farm inputs, in addition to erosion control, and positive effects on animal health and survival under winter conditions and habitat biodiversity (Brandle et al. 2004). Some of the factors affecting establishment of new agroforestry plantings include: site selection, soil type, drainage, nutrient availability, and competition from herbaceous and woody weeds. Of these, weed control was considered essential for successful establishment (Schroeder 1988). In western Canada, most agroforestry plantings are established on land that was historically grass rather than forest, and climate conditions are semi-arid with evapotranspiration exceeding precipitation, resulting in moisture deficits. Weed control practices by land managers include burning, cover cropping, tillage, herbicides, and plastic mulch application with combinations of these tailored for specific sites. Choice of weed control method was related to dominant weed species present.

Most tree species in temperate agroforestry systems are adversely affected by weed competition (Cain and Mann 1980, Cain 1991, Lauer and Glover 1999, Schroeder 1988). Agricultural fields characteristically have large dormant weed seed banks which, when planted to trees, germinate and quickly affect growth and survival (Gulden and Shirtliffe 2009). Truax and Gagnon (1993) compared the effects of three weed control treatments: straw mulch, plastic mulch and a non-weeded control on growth of white ash (Fraxinus americana L.), butternut (Juglans cinerea L.) and bur oak (Quercus macrocarpa Michx.). They found that white ash and bur oak responded positively to straw and plastic mulch whereas butternut showed no response. Their study showed that response of tree species to weed competition can be variable. Cogliastro et al. (1990) examined the effects of three weed control treatments on growth of seven species, including white ash, bur oak, black walnut (Juglans nigra L.), black cherry (Prunus serotina Ehrh.), white oak (Quercus alba L.), red oak (Quercus rubra L.) and basswood (Tilia americana L.). In their study, growth was highest in the herbicide and tillage treatments.

The importance of weed control for successful establishment of windbreaks in the Canadian prairies has been stated since the earliest land settlement. The studies by Ross (1909) at Indian Head, Saskatchewan showed that for healthy, vigorous growth of trees on the prairies it was essential to cultivate the plantings until such time as the trees were able to shade the ground sufficiently to keep down weeds and prevent excessive evaporation of soil moisture. At that time and now the greatest obstacle to tree growth on the prairies was lack of moisture, and any practical means to preserve soil moisture needed to be employed (Mitchell 1909, Pollock 2013, Schroeder 1988). Researchers have demonstrated the importance of weed control for tree growth after planting (Erdmann and Green 1967, Davies 1987, Schroeder 1988, von Althen 1989, Seifert 1993, Truax and Gagnon 1993, Jylha and Hytonen 2006, Hytonen and Jylka 2011, Meli et al. 2015, Edelfeldt et al. 2016, Henkel-Johnson 2016).
Mulching has been recognized as a beneficial practice in agronomic systems (Robinson 1988, Ham et al. 1993, Truax and Gagnon 1993, Adams 1997). Plastic mulch modifies surface radiation and reduces soil moisture losses through evaporation (Liakatas et al. 1986, Tanner 1974). This strongly affects soil temperature and soil moisture in the root zone, and in turn influences plant growth and productivity (Litzow and Pellett 1983, Robinson 1988, Truax and Gagnon 1993, Tarara 2000, Green et al. 2003). Positive effects of microclimate changes owing to mulch application have been reported on the phenology, yield, and quality of certain crops (Maiero et al. 1987, Bhella 1988, Wien and Minotti 1988). The quality of radiation reflected from certain mulches can impact aboveground plant growth (Decoteau et al. 1988, 1989) or discourage disease-carrying insect infestations (Greenough et al. 1990). Ham et al. (1991) demonstrated using computer simulation that radiation reflected from mulched surfaces affected leaf temperatures and plant water use. It is important to determine the conditions under which maximum benefits of mulch application can be realized (Robinson 1988). Mulch durability is essential as early degradation or tearing reduces effectiveness. Tree growth was better when mulch was opaque and impermeable rather than translucent (Davies 1988). This was attributed to the opaque mulch blocking sunlight which would stimulate vegetation growth under the mulch. Houle and Babeux (1994) showed that black plastic mulch had no significant effect on the growth of willow (Salix planifolia Pursh) and pine (Pinus banksiana Lamb.). Considering these studies, it is likely that tree species may respond differently to mulch applications.

Henkel-Johnson (2016) showed discrepancy in outcomes of weed control using herbicides or cultivation. Herbicide weed control was more effective than cultivation in hybrid poplar plantations, particularly when perennial grasses were the dominant competing vegetation. However, there are few studies that have investigated the relationship between tree species and weed control methods. To address issues associated with weed control methods for agroforestry species, the overall goal of this study is to show land managers how tree growth is impacted by weed competition. The specific objectives were to: 1) analyze growth of different tree species due to different levels and methods of weed control; and, 2) quantify impacts of different combinations of in- and between-row weed control on growth parameters of selected agroforestry tree species. We expected that growth of the species on agricultural soils would be negatively impacted by weed competition and would vary depending on species planted. We addressed these objectives by studying the effectiveness of three weed control practices on five commonly planted agroforestry species in Saskatchewan, Canada.

\section{Materials and Methods \\ Site description and preparation}

The experiment was conducted on an agricultural field near Indian Head, Saskatchewan ( $50^{\circ} 31^{\prime} \mathrm{N}$; $103^{\circ} 41^{\prime} \mathrm{W}$; elevation $585 \mathrm{~m}$ ) over four growing seasons (2004 to 2007). The climate at the trial site was continental with hot, dry summers and cold winters. Climate norms (1981-2010) for Indian Head show mean annual precipitation of $400 \mathrm{~mm}$ distributed mainly in spring and summer as rainfall and during the win- 


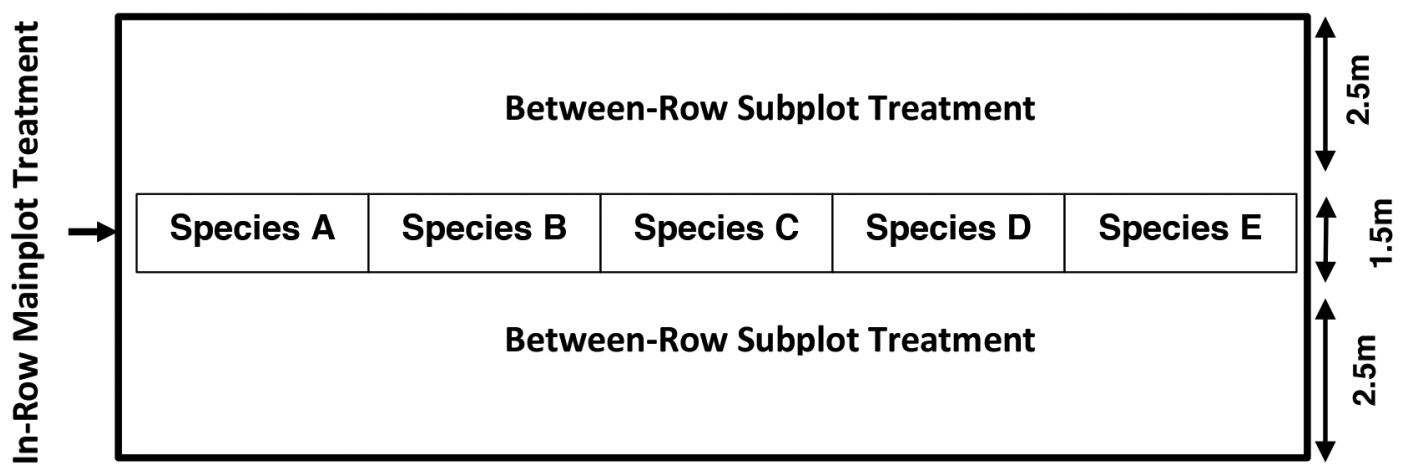

Fig. 1. Diagram representing a single experimental unit in the study

ter months as snow, and a mean annual temperature of $2.4^{\circ} \mathrm{C}$ (Environment Canada 2015). Soil type was an orthic Oxbow loam, moderately fertile with a $\mathrm{pH}$ of 7.9 and organic matter level of $3.8 \%$. The site had been in cereal grain (barley) production the year prior to trial establishment. We followed recommended site preparation practices for tree planting in temperate semi-arid regions (Schroeder 1988). This involved tillage to a depth of $20 \mathrm{~cm}$ in two directions using a tandem disc in the fall and another tillage using the same equipment and depth in the spring prior to planting.

\section{Plant material \\ Two conifers, Colorado spruce (Picea pungens Engelm.) and Scots pine (Pinus sylvestris L.) and three deciduous species, green ash (Fraxinus pennsylvanica var. subintegerrima (Vahl.) Fern.), Manitoba maple (Acer negundo L.) and Walker poplar (Populus $\mathrm{x}$ Walker) were included in this study. Seedling age ranged from 1-year-old rooted cuttings for the Walker poplar, 2 -year-old bare root seedlings for green ash and Manitoba maple, 4-year-old bare root seedlings for Scots pine and 5- year-old bare root seedlings for Colorado spruce. Deciduous seedlings were fall lifted from nursery beds and stored indoors from October to May in sealed polyethylene bags at - $4{ }^{\circ} \mathrm{C}$. The conifer seedlings were spring lifted from nursery beds in May of the planting year and stored in sealed polyeth- ylene bags at $-2{ }^{\circ} \mathrm{C}$ until planting. The seedlings were sorted so that only healthy well-rooted plants were used in the study. Care was taken to ensure that seedlings for each species had similar root development and stem caliper.}

\section{Treatments}

Bare root seedlings from each species were hand planted in single row plots in late May, 2004. Main plots had three inrow weed control levels (plastic mulch, herbicide and nonweeded) and subplots had two levels of between-row tillage (tandem disc tillage and no tillage). Plastic mulch was embossed $2.7 \mathrm{~mm}$ ultra-violet stabilized polyethylene film (PlastiTech, Saint-Remi, QC). The $1.5 \mathrm{~m}$ wide rolls of plastic were applied to the treatment plots over planted seedlings with a shop-made plastic mulch layer. Seedlings were pulled through slits in the plastic and two $15 \mathrm{~cm}$-long metal staples were used to secure the plastic at each seedling. Herbicide treatments included a combination of post- and pre-emergence herbicides applied in a $1.5 \mathrm{~m}$-wide band in the row. The post-emergence herbicide was glyphosate as $1.5 \%$ Roundup Original (Monsanto, St. Louis, MO) solution in a water carrier applied as a directed spray during the growing season as required to control vegetation. Seedlings were shielded at the time of application to prevent herbicide contact with the foliage or bark. The pre-emergence herbicide was $480 \mathrm{~g} / \mathrm{L}$ linuron as Lorox DF (DuPont Canada Inc.) applied at a rate of $4.5 \mathrm{~L} / \mathrm{ha}$. Linuron is a registered herbicide for green ash, Manitoba maple, Scots pine, Colorado spruce and poplar (Pollock 2013). Used as a pre-emergent herbicide, linuron must be incorporated into the germination zone of the soil with rainfall within 10 days of application (Schroeder 1988). The linuron was applied using a U-boom sprayer (Pollock 2013) over the row in late fall of each year in a $1.0 \mathrm{~m}$-wide band on each side of the row. With the non-weeded in-row treatment, vegetation was allowed to grow undisturbed in a $1.0 \mathrm{~m}$ band on either side of the row. Between rows, mechanical tillage was carried out to a 5- to $10-\mathrm{cm}$ depth three times per growing season (June, July and August when weed growth was present) using a single pass with a $2.5 \mathrm{~m}$-wide tandem disc at a distance of $1.0 \mathrm{~m}$ from the centre of the row, while vegetation was allowed to grow with no disturbance in a $2.5 \mathrm{~m}$-wide strip $1.0 \mathrm{~m}$ from the centre of the row in the no weed control treatment.

Each experimental unit consisted of a single row of 25 seedlings (five per species planted contiguously) with $1.75 \mathrm{~m}$ between seedlings within one main plot/subplot combination (Fig. 1). Each row was separated from adjacent treatments by $5.0 \mathrm{~m}$. The study was arranged in a three-replicate split plot design with in-row weed control the main plot treatments, and between-row weed control the subplot treatments. The between-row subplot treatments were randomly assigned within each main plot. Seedlings were randomly placed in contiguous plots within each main plot/subplot treatment.

\section{Data collection}

Five seedlings per species were measured in each treatment at the end of each of the four growing seasons. Stem basal diam- 


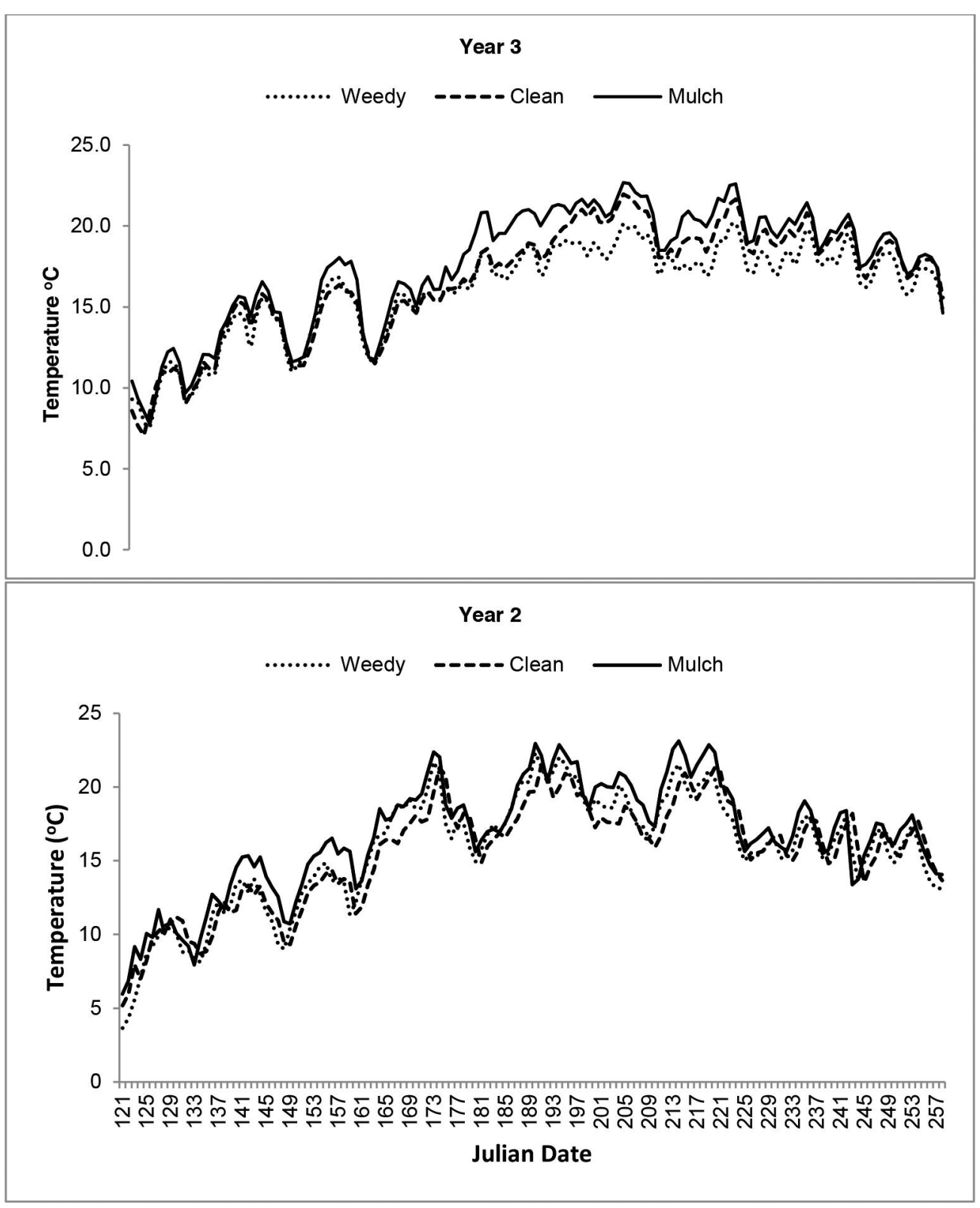

Fig. 2. Soil temperature at $20 \mathrm{~cm}$ depth in study years 2 and 3

eter at ground level was measured using electronic calipers. Seedling height (ground level to shoot apex) was measured to nearest the $\mathrm{cm}$ using a telescopic measuring pole. Annual height increment was measured to the nearest $\mathrm{cm}$ by measuring growth increment of the main leader. Data were collected on all seedlings from each treatment and replication. Seedling survival was $100 \%$ across the study and unaffected by treatments throughout the duration of the trial.

Weed biomass was measured in July of the second and third growing seasons by sampling one $1 \mathrm{~m}^{2}$ quadrat in three non-weeded between row subplots in the second year and third years. All plants present were cut at soil level and identity according to genus and species and total dry weight were determined.
Soil moisture $(\% \mathrm{~V})$ was recorded with $50-\mathrm{cm}$ long profile probes PR2 (Delta-T Devices Ltd. UK). One probe was installed in the middle of each in-row treatment plot to record root zone soil moisture at $20-\mathrm{cm}$ depth. Data were collected on a weekly basis using $\mathrm{HH} 2$ moisture meter (Delta-T Devices Ltd. UK) in years 2 and 3.

One 107B soil temperature sensor (Campbell Scientific, Edmonton Canada) was placed $20 \mathrm{~cm}$ below the soil surface in each in-row treatment plot. Sensors were connected to a CR200 datalogger (Campbell Scientific, Edmonton Canada) and programmed to record average hourly temperatures. Air temperatures and precipitation data were acquired using Campbell Scientific weather stations (Campbell Scientific, Edmonton Canada). Soil temperatures and weather data were 


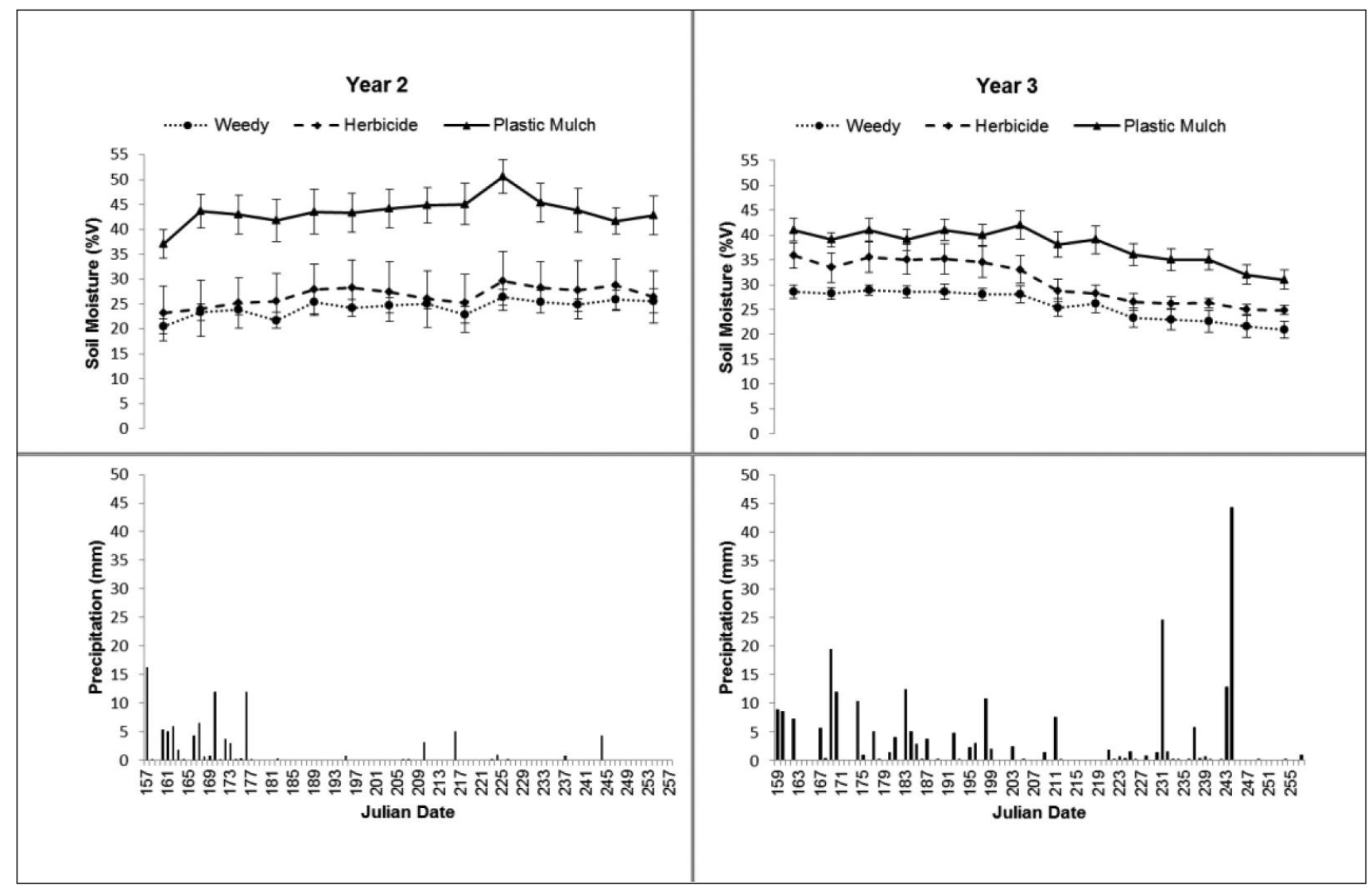

Fig. 3. Growing season precipitation and in-row soil moisture at $20 \mathrm{~cm}$ depth (Year 2 and 3)

recorded from the first week of May (Julian day 121) to midSeptember (Julian Day 258) in years 2 and 3.

\section{Statistical Analyses}

The SAS version 9.2 (SAS Institute, Cary, NC) was used for all statistical analyses. PROC UNIVARIATE was used to check normality of data. The dependent variables in the model were height, basal diameter and annual height increment. Due to variance heterogeneity and non-normality of growth variables under study, log transformation was used to prepare the data for subsequent analyses. Split plot analysis of variance (ANOVA) was conducted by species due to their different growth rates and therefore responses to weed control. SAS procedure PROC MIXED was used to analyze data from individual species for weed control treatments and their interactions. LS means were compared using Tukey's test $(\alpha=$ $0.05)$.

\section{Results and Discussion}

Effects of weed control on soil temperature and moisture

The monthly average temperatures under plastic mulch were 0.4 to $2.0^{\circ} \mathrm{C}$ higher than those of the other main plot treatments (Fig. 2). Higher below-ground temperatures as a result of mulch application have been reported by several researchers (Decoteau et al. 1989, Ham et al. 1993, Graham et al. 1995). The increase in temperatures under black plastic mulch is due to its heat transmission properties (Honma et al. 1959, Litzow and Pellett 1983). The extent of soil/plastic con- tact in regulation of soil temperatures beneath the mulch is often not given due consideration (Bonanno and Lamont 1987, Ham and Kluitenberg 1994, Cebula 1995). Higher soil temperatures promote bud break (Litzow and Pellett 1983, Truax and Gagnon 1993), possibly through increased photosynthetic activity (Brand and Janas 1988, Brand 1990, Cogliastro et al. 1990). This effect was not found in our study.

Site precipitation was considerably greater in year 3 than in year 2 (Fig. 3). Soil moisture under the mulch was significantly higher in years 2 and 3 compared to weed control using herbicide or no-weed control (Fig. 3). Plastic mulch reduces evaporation thereby conserving soil moisture (Tanner 1974, Liakatas et al. 1986) which, combined with the reduction of competing vegetation under plastic, led to higher soil moisture content under the plastic mulch. Generally soil moisture levels between herbicide and no-weed control treatments were not significantly different.

\section{Weed biomass}

At the end of year 2, non-weeded control plots had $366.6 \mathrm{~g} / \mathrm{m}^{2}$ of weed biomass; tilled, herbicide and plastic mulch treatments were kept completely weed free. By the end of year 3, weed biomass in non-weeded control plots had doubled to an average of $565.3 \mathrm{~g} / \mathrm{m}^{2}$. Weed composition in year 2 was dominated by annual weeds which shifted to biennial and perennial species by year 3 (Table 1). Weed communities developed aggressively in non-weeded plots. This was the result of large weed seed banks characteristic of prairie agricultural soils at 
Table 1. Herbaceous taxa and biomass for plots with no weed control in years 2 and 3

\begin{tabular}{|c|c|c|c|c|}
\hline \multirow[b]{2}{*}{ Species } & \multirow[b]{2}{*}{ Type } & \multirow{2}{*}{$\begin{array}{l}\text { Exotic/ } \\
\text { Native }\end{array}$} & \multicolumn{2}{|c|}{ Weed Biomass $\left(\mathrm{g} / \mathrm{m}^{2}\right)$} \\
\hline & & & Yr 2 & Yr 3 \\
\hline Hordeum vulgare L. & Annual & Native & 55.0 & 8.5 \\
\hline Setaria viridis (L.) Beauv. & Annual & Exotic & 59.4 & 45.2 \\
\hline Polyginum convolvulus L. & Annual & Exotic & 36.7 & 35.3 \\
\hline Capsella bursa-pastoris (L.) Medic. & Annual & Exotic & 35.8 & 0.0 \\
\hline Chenopodium album L. & Annual & Exotic & 35.2 & 31.1 \\
\hline Thlapsi arvense L. & Annual & Exotic & 33.8 & 0.0 \\
\hline Descurainia sophia (L.) Webb. & Annual & Exotic & 14.7 & 0.0 \\
\hline Brassica kaber (DC) L.C. Wheeler & Annual & Exotic & 12.8 & 0.0 \\
\hline Kochia scoparia (L.) Schrad. & Annual & Exotic & 8.9 & 49.5 \\
\hline Sonchus asper (L.) Hill & Annual & Exotic & 0.0 & 21.2 \\
\hline Silene noctiflora L. & Annual & Exotic & 8.9 & 0.0 \\
\hline Salsola kali L. & Annual & Exotic & 13.4 & 14.1 \\
\hline Artemisia biennis Willd. & Biennial & Native & 0.0 & 70.7 \\
\hline Erigeron canadensis L. & Biennial & Native & 8.9 & 56.5 \\
\hline Taraxacum officinale Weber & Perennial & Exotic & 31.3 & 49.5 \\
\hline Sonchus arvensis L. & Perennial & Exotic & 3.7 & 35.3 \\
\hline Cirsium arvense (L.) Scop. & Perennial & Exotic & 3.7 & 42.4 \\
\hline Hordeum jubatum L. & Perennial & Native & 4.4 & 56.5 \\
\hline Agropyron repens (L.) Beauv. & Perennial & Exotic & 0.0 & 49.5 \\
\hline Total Biomass & & & 366.6 & 565.3 \\
\hline
\end{tabular}

treatment in years 2, 3 and 4 (Table 2). Houle and Babeux (1994) observed that different pine and willow species responded to plastic mulch application differently. Between-row treatments had no significant effect on annual height increment of Scots pine. In year 4, basal diameter of Scots pine with plastic mulch was significantly greater than with herbicide or non-weeded control treatments with between-row tillage (Fig. 4B). Similarly, year 4 seedling heights were significantly larger in plastic mulch than in herbicide or weedy treatments. This is in agreement with previous findings that plastic mulch application improved establishment, growth and basal diameter in early years with reduced effect as seedlings matured (Maiero et al. 1987, Bhella 1988, Davies 1988, Wien and Minotti 1988). Between-row tillage had no impact on seedling height in plastic mulch but tended to reduce height growth in herbicide and weedy treatments (Fig. 5B). When weeds were growing adjacent to a row, the height of the study site. Gulden and Shirtliffe (2009) noted that soil weed seed banks are a critical part of the weed life cycle for many species. Aerial seed banks also were a likely source of seed for some species in the non-weeded plots. The relatively high abundance of exotic herbaceous species is typical of weed communities in cultivated prairie agricultural agroecosystems.

\section{Effects of weed control on survival and seedling growth param- eters}

Seedling survival after four years was $100 \%$ for all species and treatments. Unexpectedly, weed competition did not affect seedling survival. This may have been due to the quality of nursery seedlings and the high level of site preparation employed prior to planting. It has been demonstrated that proper and thorough site preparation is an essential component of tree planting in semi-arid prairie soils (Ross 1909, Schroeder 1988).

In-row and between-row treatment effects were observed in annual height increments of Colorado spruce (Table 2). Annual height increment under in-row mulch and herbicide treatments were significantly greater than no-weed controls during years 1 and 2 but showed no significant difference in years 3 and 4 . Annual height increment of the between-row non-weeded control treatment was significantly greater than the tillage treatment in year 4 . Between-row weed control increased basal diameter of Colorado spruce when in-row weeds were controlled with plastic mulch or herbicides (Fig. 4A). Colorado spruce height in year 4 was not affected by between-row or in-row weed control treatments (Fig. 5A). There were no statistically significant interactions between weed control treatments for the variables measured.

Scots pine was the only species where plastic mulch resulted in greater annual height increment than in herbicide seedlings with herbicide control did not differ significantly from seedlings with no in-row weed control. The significant treatment interaction for basal diameter suggested that Scots pine did not benefit from between-row weed control and only plastic mulch resulted in a growth advantage. Desiccating winds and snow abrasion can lead to needle loss and growth limitation in conifers (Holtmeier and Broll 2011). Winter desiccation can occur when conifer needles are unprotected from cuticular transpiration (Hadley and Smith 1986). In this study, tall weeds adjacent to the row protected the young Scots pine from desiccating winds. The protective function of the weeds appeared to outweigh their competitive effects; the combination of in-row weed control using plastic mulch with a border of weed growth adjacent to the row provided the best environment for height growth of Scots pine.

The annual height increment of the three deciduous species was similar for plastic mulch and herbicide in-row weed control treatments which was significantly greater in all years than in the non-weeded control treatment (Table 2). When between-row treatments were compared, tillage after year 1 significantly increased annual height increment of the three species in all years except year 1 where no significant differences were evident. Year 4 basal diameters and heights of green ash (Fig. 4C and 5C), Manitoba maple (Fig. 4D and 5D) and Walker poplar (Fig. 4E and 5E) were significantly greater with in-row weed control (herbicides or plastic mulch) than with the non-weeded control. The same trend followed for between-row treatments where tillage resulted in significantly greater basal diameters and heights for the three species. There were no statistically significant interactions between weed control treatments with variables measured for the three deciduous species. Overall, plastic mulch did not improve growth of the species when compared with the herbicide treatment. Green et al. (2003) showed early growth 


\begin{tabular}{|c|c|c|c|c|c|c|}
\hline \multirow[b]{3}{*}{ Tree Species } & \multirow[b]{3}{*}{ Treatment } & \multirow[b]{3}{*}{ Weed Control Method } & \multicolumn{4}{|c|}{ Annual Height Increment (cm) } \\
\hline & & & \multicolumn{4}{|c|}{ Study Year } \\
\hline & & & Yr-1 & Yr-2 & Yr-3 & Yr-4 \\
\hline \multirow[t]{5}{*}{ Colorado spruce } & In-Row Mainplot & Plastic Mulch & $4.45 \mathrm{a}$ & $10.64 a$ & $20.13 a$ & $23.09 \mathrm{a}$ \\
\hline & & Herbicide & $4.66 \mathrm{a}$ & $8.33 b$ & $21.68 \mathrm{a}$ & $17.84 \mathrm{a}$ \\
\hline & & Non-weeded control & $5.43 \mathrm{~b}$ & $8.52 b$ & 20.41a & $20.40 \mathrm{a}$ \\
\hline & Between-Row Subplot & Tillage & $5.00 \mathrm{a}$ & $9.12 \mathrm{a}$ & $20.41 \mathrm{a}$ & $17.89 \mathrm{a}$ \\
\hline & & Non-weeded control & $4.66 \mathrm{a}$ & $9.10 \mathrm{a}$ & $21.06 \mathrm{a}$ & $23.21 b$ \\
\hline \multirow[t]{5}{*}{ Scots pine } & In-Row Mainplot & Plastic Mulch & $11.96 \mathrm{a}$ & $21.88 \mathrm{a}$ & $39.64 a$ & $55.55 \mathrm{a}$ \\
\hline & & Herbicide & $10.12 \mathrm{a}$ & $14.12 \mathrm{~b}$ & $28.68 b$ & $43.29 b$ \\
\hline & & Non-weeded control & $11.18 \mathrm{a}$ & $16.25 b$ & $25.34 b$ & $34.09 \mathrm{c}$ \\
\hline & Between-Row Subplot & Tillage & $11.04 \mathrm{a}$ & $16.46 \mathrm{a}$ & 28.51a & $41.64 \mathrm{a}$ \\
\hline & & Non-weeded control & $11.08 \mathrm{a}$ & $17.81 \mathrm{a}$ & $32.98 \mathrm{a}$ & $45.56 \mathrm{a}$ \\
\hline \multirow[t]{5}{*}{ Green ash } & In-Row Mainplot & Plastic Mulch & $13.82 \mathrm{a}$ & $44.72 \mathrm{a}$ & $35.27 \mathrm{a}$ & $32.36 \mathrm{a}$ \\
\hline & & Herbicide & $17.15 a$ & $43.20 \mathrm{a}$ & $37.15 \mathrm{a}$ & $36.56 a$ \\
\hline & & Non-weeded control & $8.03 \mathrm{~b}$ & $13.53 b$ & $12.06 \mathrm{~b}$ & $11.24 \mathrm{~b}$ \\
\hline & Between-Row Subplot & Tillage & $12.06 \mathrm{a}$ & $34.91 \mathrm{a}$ & $40.51 \mathrm{a}$ & $38.70 \mathrm{a}$ \\
\hline & & Non-weeded control & $12.74 \mathrm{a}$ & $25.23 b$ & $15.55 b$ & $13.72 b$ \\
\hline \multirow[t]{5}{*}{ Manitoba maple } & In-Row Mainplot & Plastic Mulch & $16.95 b$ & $52.63 a$ & $39.73 a$ & $39.70 \mathrm{a}$ \\
\hline & & Herbicide & $22.76 a$ & $54.65 a$ & $38.38 \mathrm{a}$ & $41.83 a$ \\
\hline & & Non-weeded control & $14.24 \mathrm{~b}$ & $17.26 \mathrm{~b}$ & $20.45 b$ & $22.35 b$ \\
\hline & Between-Row Subplot & Tillage & $18.64 \mathrm{a}$ & $43.37 \mathrm{a}$ & $45.59 \mathrm{a}$ & $48.55 a$ \\
\hline & & Non-weeded control & $16.70 \mathrm{a}$ & $31.14 \mathrm{~b}$ & $21.73 b$ & $37.75 b$ \\
\hline \multirow[t]{5}{*}{ Walker poplar } & In-Row & Plastic Mulch & $60.99 a$ & $122.43 a$ & $175.73 a$ & $167.11 \mathrm{a}$ \\
\hline & & Herbicide & $70.35 a$ & $116.00 \mathrm{a}$ & $146.66 \mathrm{a}$ & $162.56 \mathrm{a}$ \\
\hline & & Non-weeded control & $38.41 \mathrm{c}$ & $78.31 b$ & $101.62 b$ & $111.79 \mathrm{~b}$ \\
\hline & Between-Row & Tillage & $48.72 \mathrm{a}$ & $133.12 \mathrm{a}$ & $162.02 \mathrm{a}$ & $172.19 \mathrm{a}$ \\
\hline & & Non-weeded control & $54.75 a$ & $80.63 \mathrm{a}$ & $117.27 \mathrm{~b}$ & $111.62 \mathrm{~b}$ \\
\hline
\end{tabular}

Columns with same letter in the treatment associated with each tree species do not differ significantly at $\mathrm{P}>0.05$.

improvements for poplar with plastic mulch in short-rotation woody crop plantations on low quality sites; the benefit was less evident on high quality sites. Our site was considered to have medium agricultural capability. Deciduous root systems expand rapidly in agricultural soils, meaning that after two to three years, root systems would reach beyond the protective area of the plastic allowing seedlings to obtain nutrients and moisture from a larger area. The importance of weed control was demonstrated for all three species when the influence of in-row and between-row weed control was compared to nonweeded controls. Other than year 1, in-row and between-row weed control significantly increased growth of the three species.

By year 4, all species showed growth benefits with the use of a least one weed control treatment. No single weed control combination worked best for all species in the study. Ranking of treatments are shown in Table 3. The variance among ranks for species and treatments illustrates that one practice does not suit all. Plastic mulch combined with between-row tillage resulted in the tallest seedlings for Walker poplar. The in-row herbicide combined with tillage between-row treatment resulted in the tallest seedlings for Manitoba maple and green ash whereas the herbicide in-row combined with the nonweeded between-row treatment produced the tallest Colorado spruce. For Scots pine, the plastic mulch combined with tillage between-row was best with the plastic mulch/non-weeded between-row treatments a close second. This complicates weed management in multi-species agroforestry plantings where it is difficult to employ multiple weed control methods. At least one in-row treatment (plastic mulch) ranked number 1 or 2 for five of the six species. For all species, using at least one weed control treatment was superior to the non-weeded control.

The most dramatic impact of weed control treatment was with green ash which showed a $3.6 \mathrm{x}$ increase in year 4 total heights and $5.4 \mathrm{x}$ in basal diameter when compared to the poorest treatment in the study. Conversely, differences between the best and worst treatment for Colorado spruce was $1.1 \mathrm{x}$ increase for height and $1.9 \mathrm{x}$ increase for basal diameter. In general, weed competition had a greater impact on basal diameter growth than overall height for all species.

The value of tillage adjacent to trees has been debated by 


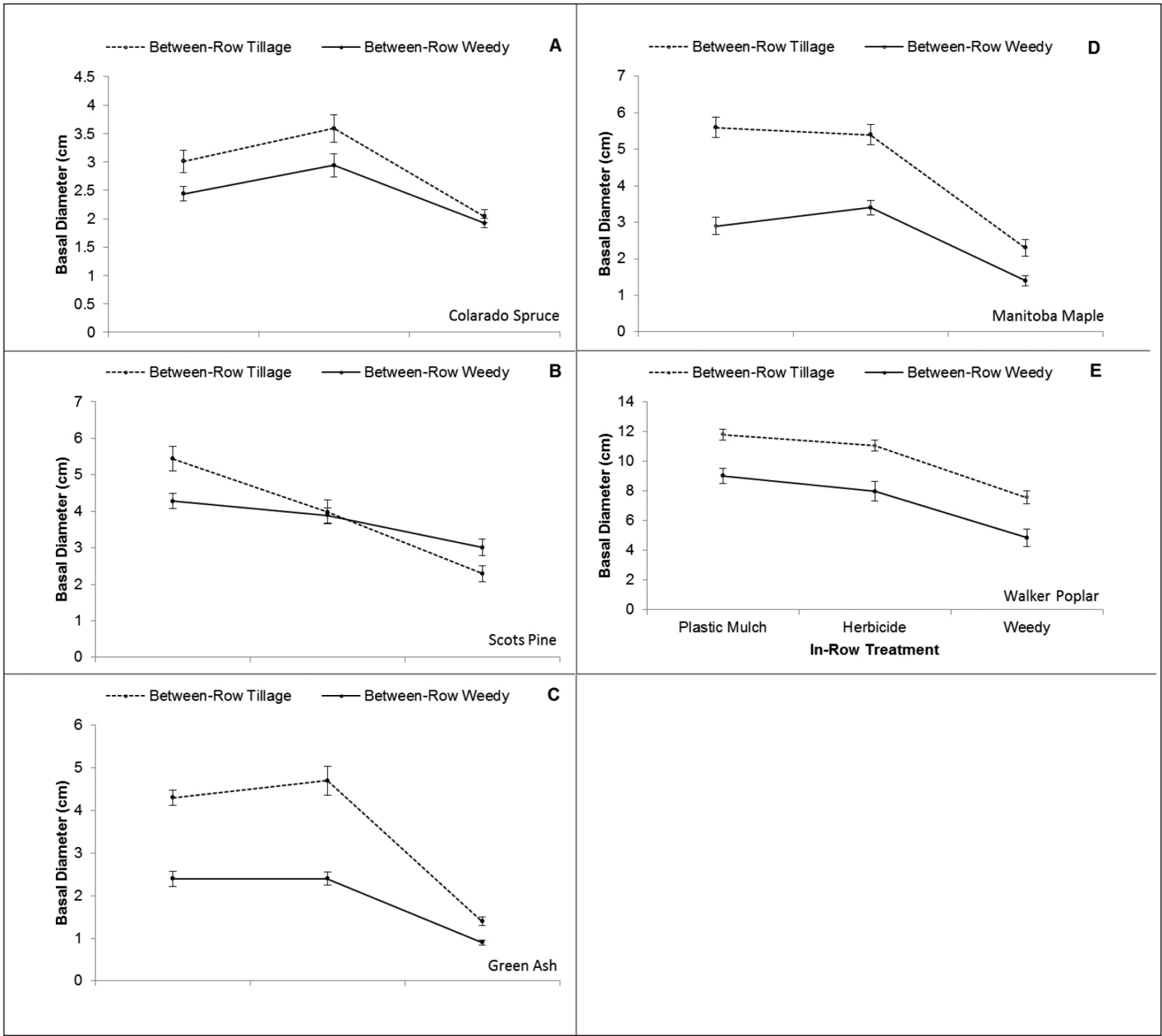

Fig. 4. Basal diameter of Colorado spruce (A), Scots pine (B), green ash (C), Manitoba maple (D) and Walker poplar (E) at Year 4

land managers. Our results suggest that for coniferous species, tillage did not provide a significant benefit. On the other hand, deciduous species responded positively to tillage adjacent to the tree row.

\section{Conclusions}

Weed control positively affected annual height increment and total basal diameter and height of the five agroforestry species in this study. The positive impact of weed control versus noweed control was significant in almost all instances. However, species responded differently to the method of control. Weed control by herbicide and plastic mulch were not significantly different with only the exception of Scots pine. However, because plastic is relatively easy to apply in agricultural soils and did not adversely affect any of the species tested, we recommend the use of plastic mulch for agroforestry plantings particularly if they include Scots pine.
The response of agroforestry species in this study to weed control was variable. Overall weed control had a greater impact on growth of the deciduous species than on the conifers. The largest most significant growth response was with green ash; without weed control, growth of this species was negligible. For successful establishment of green ash in agroforestry systems, significant effort to control weeds is required. Both between-row tillage and in-row weed control, either with herbicide or using plastic mulch, is essential.

It has been well-established in this study and in others (Miller and Zutter 1989, Knowe et al. 1992, Hytonen and Jylka 2011, Henkel-Johnson et al. 2016) that weed control has a positive effect on species establishment. The question is: Which method of weed control for planting on agricultural soils is the most efficient and economical? The answer will depend upon site conditions and species and may involve more than one type of measure to be adopted (Henkel-John- 


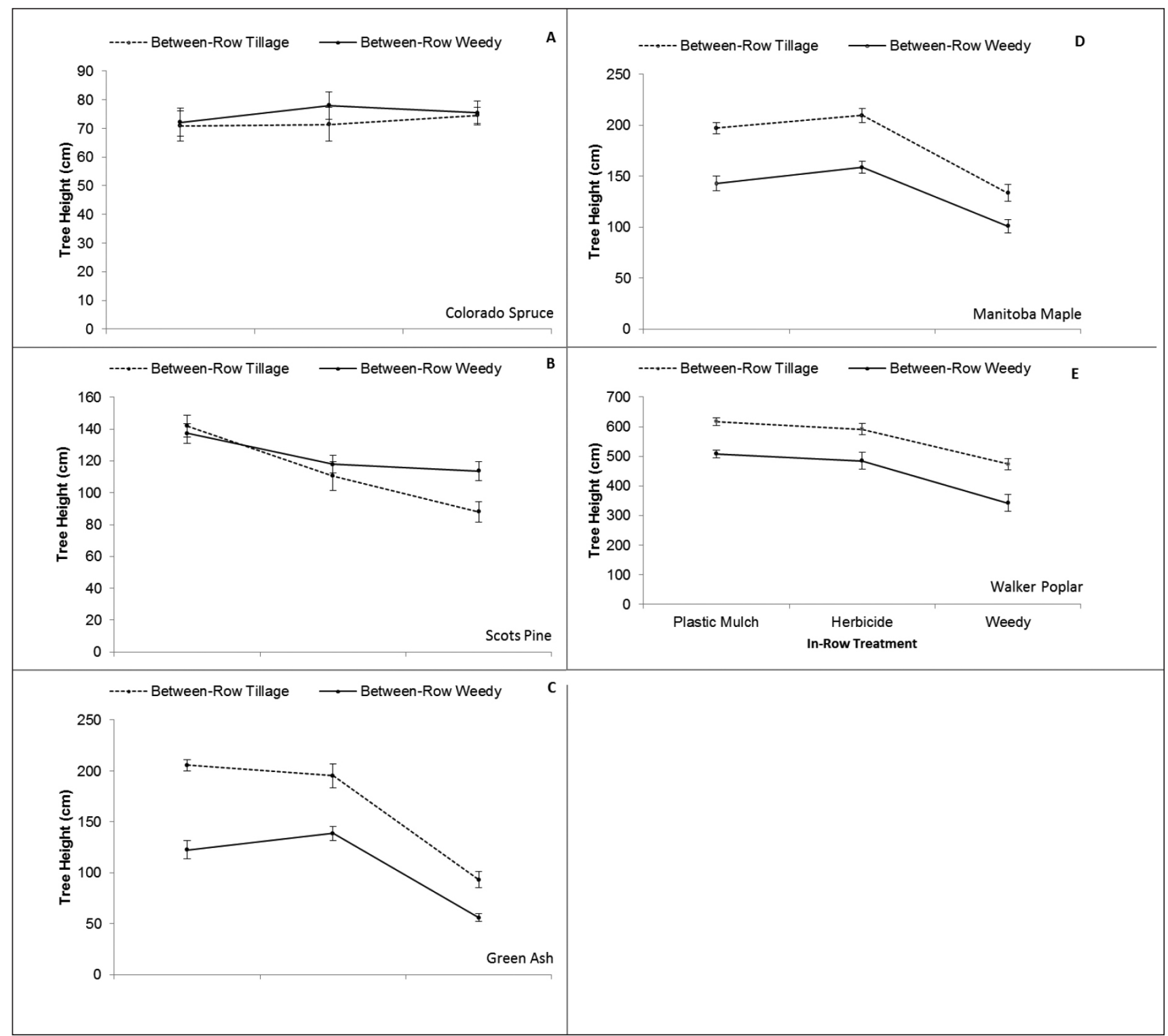

Fig. 5. Tree height of Colorado spruce (A), Scots pine (B), green ash (C), Manitoba maple (D) and Walker poplar (E) at Year 4

Table 3: Ranking of weed control treatments based on tree height after four years

\begin{tabular}{lccccc}
$\begin{array}{l}\text { In-Row/Between-Row } \\
\text { Treatments }\end{array}$ & $\begin{array}{c}\text { Manitoba } \\
\text { Maple }\end{array}$ & $\begin{array}{c}\text { Green } \\
\text { Ash }\end{array}$ & $\begin{array}{c}\text { Walker } \\
\text { Poplar }\end{array}$ & $\begin{array}{c}\text { Scots } \\
\text { Pine }\end{array}$ & $\begin{array}{c}\text { Colorado } \\
\text { Spruce }\end{array}$ \\
\hline Plastic/Tillage & 2 & 2 & 1 & 1 & 2 \\
Plastic/Non-Weeded Control & 4 & 4 & 3 & 2 & 4 \\
Herbicide/Tillage & 1 & 1 & 2 & 3 & 1 \\
$\begin{array}{l}\text { Herbicide/Non-Weeded Control } \\
\text { Non-Weeded Control/Tillage }\end{array}$ & 3 & 3 & 4 & 4 & 3 \\
Non-Weeded Control/ & 5 & 5 & 5 & 6 & 5 \\
$\quad$ & & & & & \\
$\quad$ Non-Weeded Control & 6 & 6 & 6 & 5 & 6 \\
\hline
\end{tabular}

son 2016). Standard practice for tree establishment in semiarid and temperate regions is that the soil is well-prepared and free of weeds at the time of planting (Talbert 2008, Schroeder 1988, Pollock 2013). Post-planting weed control can be achieved either by the use of herbicide, tillage or plastic mulch. The use of herbicide or tillage to control weeds is a continuous effort requiring multiple chemical applications or tillage operations during the growing season; this requires time and resources. All other factors being the same, plastic mulch provides long-term cost-effective weed control. The only associated initial investment is the cost and application. There are no ongoing costs and the additional moisture and higher soil temperatures aid growth. Higher soil moisture content will result in higher survival and growth, particularly in drought years. 


\section{References}

Adams, J.C. 1997. Mulching improves early growth of four oak species in plantation establishment. South J. Appl. For. 21(1):44-46. Bhella, H.S. 1988. Tomato response to trickle irrigation and black polyethylene mulch. J. Amer. Soc Hort. Sci. 113:543-546.

Bonanno, A.R. and W.J. Lamont Jr. 1987. Effect of polyethylene mulches, irrigation method, and row covers on soil and air temperature and yield of muskmelon. J. Amer. Soc. Hort. Sci. 112(5): 735-738.

Brand, D.G. 1990. Growth analysis of responses by planted white pine and white spruce to changes in soil temperature, fertility, and brush competition. Forest Ecol. and Manage. 30(1-4):125-138.

Brand, D.G. and P.S. Janas 1988. Growth and acclimation of planted white pine and spruce seedlings in response to environmental conditions. Can. J. For. Res. 18:320-329.

Brandle, J.R., L. Hodges and X.H. Zhou. 2004. Windbreaks in North American agricultural systems. Agroforestry Systems 61:65-78.

Cain, M.D. 1991. The influence of woody and herbaceous competition on early growth of naturally regenerated loblolly and shortleaf pines. South J. Appl. For. 15(4):179-185.

Cain, M.D. and W.F. Mann Jr. 1980. Annual brush control increases early growth of loblolly pine. South. J. Appl. For. 4(2):67-70.

Cebula, S. 1995. Black and transparent plastic mulches in greenhouse production of sweet pepper. II. Light conditions and the generative development of plants. Folia Hortic. Sin. 7(2): 59-67.

Cogliastro, A. D. Gagnon, D. Coderre and P. Bhereur. 1990. Response of seven hardwood tree species to herbicide, rototilling and legume cover at two southern Quebec plantation sites. Can. J. For. Res. 20(8): 1172-1182.

Davies, R.J. 1987. Trees and weeds: Weed control for successful tree establishment. Forestry Commission Handbook 2. HMSO Publications Centre, London UK.

Davies, R.J. 1988. Sheet mulching as an aid to broadleaved tree establishment. I. Effectiveness of various synthetic sheets compared. Forestry 61(2):89-105.

Decoteau, D.R., M.J. Kasperbauer and P.G. Hunt. 1989. Mulch surface color affects yield of fresh-market tomatoes. J. Amer. Soc. Hort. Sci. 114:216-219.

Decoteau, D.R., M.J. Kasperbauer, D.D Daniels and P.G. Hunt. 1988. Plastic mulch color effects on reflected light and tomato plant growth. Sci. Hortic. 34:169-175.

Edelfeldt, S., A Lundkvist, J. Forkman and T. Verwijst. 2016. Establishment and early growth at different levels of weed competition and nitrogen fertilization. Bioenerg. Res. 9:763-772.

Environment Canada. 2015. Canadian Climate Normals and Averages 1981-2010 Station Data. http://climate.weather.gc.ca/climate_ normals/index_e.html. Accessed 11 February 2015.

Erdmann, G.G. and L. Green. 1967. Chemical weed control in a two-year-old walnut planting. Res. Note NC-28, St. Paul MN; U.S. Dept Agric, For Sev., North Central For Exp Ctr.

Graham, H.A.H., D.R. Decoteau and D.E. Linvill 1995. Development of a polyethylene mulch system that changes color in the field. HortScience 30:265-269.

Green, D.S., E.L. Kruger and G.R. Stanosz. 2003. Effects of polyethylene in a short-rotation, poplar plantation vary with weedcontrol strategies, site quality and clone. For. Ecol. Manage. 173:251-260.

Greenough, D.R., L.L. Black and W.P. Bond. 1990. Aluminum-surfaced mulch: An approach to the control of tomato spotted wilt virus in solanaceae crops. Plant Dis. 74:805-808.

Gulden, R.H. and S.J. Shirtliffe. 2009. Weed seed banks: Biology and management. Prairie Soils and Crops Journal 2:46-52.

Hadley, J.L and W.K. Smith. 1986. Wind effects on needles of timberline conifers: Seasonal influence on mortality. Ecology 67(1):12-19.
Ham, J.M. and G.T. Kluitenberg. 1994. Modeling of the effect of mulch optical properties and mulch soil contact resistance on soil heating under plastic mulch culture. Agr. Forest. Meteorol. 71:403-424.

Ham, J.M., G.T. Kluitenberg and W.J. Lamont. 1991. Potential impact of plastic mulches on the aboveground plant environment. Proceedings Natural Agricultural Plastics Congress (23 $\left.{ }^{\text {rd }}\right)$ p.63-69.

Ham, J.M., G.T. Kluitenberg and W.J. Lamont. 1993. Optical properties of plastic mulches affected the field temperature regime. J. Amer. Soc. Hort. Sci. 118:188-193.

Henkel-Johnson, D., S.E. MacDonald, E.W. Bork and B.R. Thomas. 2016. Influence of weed composition, abundance, and spatial proximity on growth in young hybrid poplar plantations. For. Ecol. Manage. 362:55-68.

Holtmeier, F.K. and G. Broll. 2011. Response of Scots pine (Pinus sylvestris) to warming climate at its altitudinal limit in northernmost subarctic Finland. Arctic 64: 269-280.

Honma, S., F. McHardle, J. Carew and D.H. Dewey. 1959. Soil and air temperature as affected by polyethylene mulches. Mich. Exp. Stn. Q. Bull. 41:834-842.

Houle, G. and P. Babeux. 1994. Fertilizing and mulching influence on the performance of four native woody species suitable for revegetation in subarctic Quebec. Can. J. For. Res. 24:2342-2349.

Hytonen, J. and P. Jylha. 2005. Effects of competing vegetation and post-planting weed control on the mortality and growth of and damage caused by voles to Betula pendula when planted on former agricultural land. Silva Fenn. 39(3):365-380.

Hytonen, J. and P. Jylha. 2011. Long-term response of weed control intensity on Scots pine survival, growth and nutrition on former arable land. Eur. J. Forest Res. 130 (1): 91-98.

Jylha, P. and J. Hytonen. 2006. Effect of vegetation control on survival and growth of Scots pine (Pinus sylvestris L. and Norway spruce (Picea abies (L.) Karst) planted on former agricultural land. Can. J. For. Res. 36:2400-2411.

Knowe, S.A., D.D. Shiver and W.N. Kline. 1992. Fourth-year response of loblolly pine following chemical and mechanical site preparation in the Georgia Piedmont. South J. Appl. For. 16(2):99-105.

Lauer, D.K. and G.R. Glover. 1999. Stand level pine response to occupancy of woody shrub and herbaceous vegetation. Can. J. For. Res. 29:979-984.

Liakatas, A., J.A.Clark and J.L. Monteith. 1986. Measurements of the heat balance under plastic mulches. Part I. Radiation balance and soil heat flux. Agr. Forest Meteorol. 36:227-239.

Litzow, M. and H. Pellett. 1983. Influence of mulch materials on growth of green ash. Arboriculture and Urban Forestry 9(1):8-11.

Maiero, M., F.D. Schales and T.J. Ng. 1987. Genotype and plastic mulch effects on earliness, fruit characteristics, and yield in muskmelon. HortScience 22:945-946.

Meli, P., J.M.R. Benayas, M.M. Ramos and J. Carabias. 2015. Effects of grass clearing and soil tilling on establishment of planted tree seedlings in tropical riparian pastures. New Forests 46:507-525. Miller, J.H. and B.R. Zutter. 1989. A region-wide study comparing woody vs. herbaceous competition on loblolly pine growth. Proc. South Weed Sci. Soc. 42:233.

Mitchell, A. 1909. The tree planting problem in western Saskatchewan and southern Alberta. Can. Forestry J. 5(2):126-130.

Pollock, T. 2013. Controlling weeds in your agroforestry planting. Agriculture and Agri-Food Canada, Indian Head, Saskatchewan. [Online] http://www.agr.gc.ca/eng/science-and-innovation/agricultural-practices/agroforestry/growth-and-maintenance-of-trees/controlling-weeds-in-your-agroforestry-planting/?id=1346110876860 [accessed 12 September 2016].

Robinson, D.W. 1988. Mulches and herbicides in ornamental plantings. HortScience 23(3):547-552. 
Ross, N.M. 1909. General suggestions for the preparation of the soil for tree planting on the prairies. Circular No. 1, Dept. of Interior, Forestry Branch. Ottawa Ontario. $3 \mathrm{p}$

Schroeder, W.R. 1988. Planting and establishment of shelterbelts in humid-severe winter regions. Agric. Ecosystems Environ. 22/23:441-463.

Seifert, J.R. 1993. Weed control for tree and shrub seedlings. Purdue University, Cooperative Extension Service, West Lafayette, IN. FNR-135.

Talbert, C. 2008. Achieving establishment success the first time. Tree Planter's Notes 52(2):31-37.

Tanner, C.B. 1974. Microclimatic modification: Basic Concepts. HortScience 9:555-560.
Tarara, J.M. 2000. Microclimate modification with plastic mulch. HortScience 35(2):169-180.

Truax, B. and D. Gagnon. 1993. Effects of straw and black plastic mulching on the initial growth and nutrition of butternut, white ash, and bur oak. For. Ecol. Manage. 57:17-27.

von Althen, F.W. 1989. Effects of weed control and irrigation on 7and 8-year growth of planted black walnut. In: I.E. Phelps Ed. Continuing quest for quality: Proceedings of the $4^{\text {th }}$ Black Walnut Symposium, Carbondale IL August 1989, pp. 103-113.

Wien, H.C. and P.L. Minotti. 1988. Increasing yield of tomatoes with plastic mulch and apex removal. J. Amer. Soc. Hort. Sci. 113:342-347. 